DOI 10.23947/2414-1143-2019-19-3-20-24

UDC 811.351.42+811.161.1

\title{
LANGUAGE PERSONALITY IN THE CONDITIONS OF THE CHECHEN-RUSSIAN BILINGUALISM
}

\author{
(C) Raisa S. llyasova \\ Chechen State University, Grozny, Russian Federation \\ science-almanac@mail.ru
}

The language personality is considered. This phenomenon is absolutely social, but it also has an individual aspect. The language personality is a concrete person with his own consciousness, free will, with complex inner world and individual attitude to the environment. Vainakh-Russian relations have a centuries-long history. Researchers note that as early as 7-8 centuries AD Caucasian peoples traded with the Slavs. The studies of historians also prove the presence of early ties with Kievan Rus. The originality of culture allows the ethnos to preserve and carry through its centuries its ethnic identity and originality, cultural codes that, through the millennia, rediscover the spiritual secrets and treasures of distant ancestors for the descendants, fill them with new meaning and ideas consistent with time. The universality of culture allows people to find a common language of communication and cultural interaction with other nations, primarily neighboring ones, their place in the cultural spectrum of a multinational state. The cultural isolation of the people leads to the degeneration of its culture, to the loss of identity, to the cultural assimilation. Today, the language personality is understood as a specific speaker of a language capable of understanding, creating and reproducing texts, this is a person who is able, based on the analysis of the texts produced by him, to reflect the vision of the surrounding reality. The doctrine of the language personality is developed by means of the scientific paradigm, which is accompanied by the use of various methods, techniques, methods of research of language material. In each case, their choice is determined by goals and objectives. It is established that each such personality is formed on the basis of the acquisition by the particular person of all the linguistic wealth created by predecessors. The language of the particular person still consists of general and individual language features.

Key words: language, personality, people, the Chechen language, the Russian language, cultural studies, vocabulary, language means, the national language.

\section{[P.С. Ильясова Языковая личность в условиях чеченско-русского двуязычия]}

Рассматривается языковая личность - явление безусловно социальное, но в ней есть и индивидуальный аспект. Языковая личность - это конкретный человек со своим сознанием, свободой воли, сложным внутренним миром и индивидуальным отношением к окружающему. Вайнахско-русские отношения насчитывают многовековую историю. Исследователи отмечают, что еще в VII-VIII веках н.э. кавказские народы вели торговлю со славянами. Также исследования историков доказывают наличие ранних связей с Киевской Русью. Самобытность культуры позволяет этносу сохранить и пронести через века свою этническую идентичность и своеобразие, культурные коды, которые через тысячелетия открывают потомкам заново духовные тайны и сокровища далеких предков, наполняют их новым смыслом и идеями, сообразными времени. Универсальность культуры позволяет народу найти единый язык общения и культурного взаимодействия с другими народами, прежде всего соседними, свое место в культурном спектре многонационального государства. Культурная изоляция народа ведет к вырождению его культуры, утрате самобытности - к культурной ассимиляции. На сегодняшний день языковую личность понимают как конкретного носителя языка, способного понимать, создавать и воспроизводить тексты, это личность, способная на основе анализа произведенных ею текстов отражать видения окружающей действительности. Учение о языковой личности разрабатывается средствами научной парадигмы, которое сопровождается использованием разных методов, приемов, способов исследования языкового материала. В каждом конкретном случае их выбор определяется целями и задачами. Устанавливается, что каждая такая личность формируется на основе приобретения конкретным человеком всего языкового богатства, созданного предшественниками. Язык конкретной личности все-таки состоит из общего и индивидуальных языковых особенностей.

Ключевые слова: язык, личность, народ, чеченский язык, русский язык, культурология, лексика, языковые средства, национальный язык. 
Raisa S. Ilyasova - Ph.D. in Philology, Associate Professor, Chechen State University, Grozny, Russian Federation.

Ильясова Раиса Сайтхасановна - кандидат фрилологических наук, доцент, Чеченский государственный университет, е. Грозный, Российская Федерация.

Nowadays the problem of the language personality gains special sharpness as there is a great number of addressers creating their texts. However, not everything that is created in the speech by people is worth imitating and not everything is intended for storage, the most part of products of speech activity is consumed, wears out and loses its value.

The language individual represents the difficult phenomenon, which demands the deep analysis and comprehensive observation. The language personality is a concrete person with his own consciousness, free will, with his complex inner world and individual attitude to the environment. The person by his nature is a social being and therefore he acts as the subject of sociocultural life.

In the beginning the concept of the language personality was developed by G.I. Bogin, he created a type of the language personality in which the person was considered in terms of his readiness to make speech activity, to create and accept works of speech [1]. Yu.N. Karaulov has introduced the considered concept into the broad scientific use, he considers that the language personality is a person having the ability to create and perceive texts [3].

Within the last decades, the base of studying of the language personality is saved up. Articles, scientific and research works are devoted to its description. The modern linguistic cultural science puts the following components into the content of the language personality:

1) the valuable, world outlook component of the content of education, that is the system of values or vital meanings, put in each person from the very beginning of his formation as a society, the system of process in which the major place is taken by the language. The language provides an initial and deep view of the formed and created identity of the person of the world, it forms that language image of the world and the hierarchy of spiritual representations which are the cornerstone of the formation of national character and which are implemented in the course of language dialogue communication;

2) the culturological component is a level of the development of culture as effective remedy of increase of interest in the language. Attraction in formation of the linguistic identity of the facts of culture of his native (or studied) language, connected with rules of speech and of nonverbal behavior, promotes the formation of skills of the adequate use and the effective impact on the partner in communication;

3) the personal component, that is individual and deep, that is in each person as in the individual connected with the first two components, but it is not limited by this.

Great achievements of the Cultural Revolution, improvement and creation of writings, elimination of illiteracy, transition to the Russian graphic system, fast development of education in the uniform system of federation, predetermined the existence of the general features in the interaction of the people of the North Caucasus and their languages with the Russian people and with their language.

The city of Grozny, the capital of the former Checheno-Ingush Autonomous Soviet Socialist Republic, (nowadays the capital of the Chechen Republic), considerably differed in character and in intensity of ethnolanguage processes in comparison with other part of the republic. The developed industry, the education system, the high educational and cultural level of the population, its multinationalism directed to the merge of the nations, the national 
and language policy contributed to the development of bilingualism mostly. As Ovkhadov M. R. notes: "The events of the last years of the 20th century on the scales are incommensurable to the results of the first Chechen campaign. Migration of the Chechen people out of borders of the republic not only promotes the development of bilingualism, but considerably promotes the transition to the second language of the generation which is especially growing up out of the Chechen environment" [4, p. 87].

The culture of the Chechen people is original and unique. Its roots consume life blood of spiritual consciousness of the people, it exists and develops in diverse connections with cultures of other Caucasian people first of all living in one landscape and geographical zone. The main thing interaction in the last century happens to the rich Russian culture, literature and language of the Russian people. Through these communications there is mutual enrichment and interference of cultures of the different people, formation of certain cultural archetypes, and in case of intensity and duration of cultural interaction - formation of cultural communities which have supranational and non-denominational character. The identity of culture allows the Chechen people to keep and to carry through the centuries the ethnic identity and originality, cultural codes which in the millennia rediscover spiritual secrets and treasures of far ancestors to the descendants, fill them with the new sense and ideas corresponding to time. The universality of culture allows the people to find the common language of communication and cultural interaction with other people, first of all, with neighboring people, and to find the place in the cultural range of the multinational state. The cultural isolation of the people leads to the degeneration of its culture, to the loss of identity, to the cultural assimilation.

Today, the language personality is understood as a specific speaker of a language capable of understanding, creating and reproducing texts, this is a person who is able, based on the analysis of the texts produced by him, to reflect the vision of the surrounding reality.

The basis for characteristic of the language personality is considered to be the threelevel structure offered by Yu.N. Karaulov:

1) the verbal and semantic level which reflects the extent of possession of the language personality of a simple language;

2) the cognitive level at which there is an updating and identification of the relevant knowledge and of representations of the language personality creating collective and/or individual cognitive space; this level assumes reflection of the language model of the world of the personality, its thesaurus, culture;

3) the pragmatical level, the highest level which includes identification and characteristic of motives and purposes moving the development of the language personality.

Further the structuring of the language personality was rethought by Yu.N. Karaulov, the structure was added and specified in the works of other scientists. So, V.A. Maslova allocates three components studying the language personality:

1) the valuable (world outlook) component, that is a system of values or of vital meanings which are put in each person from the very beginning of his formation as the individual.

2) the culturological component, that is a level of the development of culture as means of increase of interest in language.

3) the personal component, that is in each person as an individual connected with the first two components, but it is not limited by this.

Studying the language personality in such direction, the researchers established that parameters of each language personality are characterized by the certain vocabulary, which, in turn, has this or that rank of the rate of use. These words united by the rules adopted in this language fill abstract syntactic models. If such models are rather typical for the representative of this language collective (Russian, Tatar, Bashkir, etc.), then the lexicon and the manner of speaking can indicate the belonging of the personality to the certain society, they 
help to learn about the level of his education, character type, they even can point to the sex, age, etc.

The language personality exists in the space of culture reflected in the natural language, in the forms of public consciousness at the different levels (scientific, household), in behavioral norms, in pieces of material culture. The defining role in the culture belongs to values of the nation which possesses the language and culture, and these values are concepts of meanings.

The doctrine of the language personality is developed by means of the scientific paradigm, which is accompanied by the use of various methods, techniques, methods of research of language material. In each case, their choice is determined by goals and objectives.

The all-inclusiveness of culture allows the people to find the common language of communication and of cultural interaction with neighboring people and to find the place in the cultural range of the multinational state. The cultural isolation of the people leads to the degradation of its culture, to the loss of identity, i.e. to the cultural assimilation.

Information about the interaction of the Russian and Chechen literatures, about the interinfluence of the Chechen and Russian languages and about the development of the Chechen-Russian bilingualism as a result of this interaction is noted in a number of researches: $[2,8]$, etc.

In the Chechen culture, all types and genres peculiar to the cultures of other people are presented. At the same time, the Chechen culture has its own feature that is defined by the geographical location, confessional features and ethnocultural environment.

The degree of development of bilingualism in the Chechen Republic in the eighties of the last century was an initial stage of transition from the Chechen-Russian bilingualism to the second, i.e. the Russian language. Excessively high scale of the Russian lexical interspersing in the Chechen speech is one of the ways of transition to the Russian language.

Russian as a language of teaching takes the main place in education of the Chechen Republic. The Chechen language performs function of a subject of studying.

The language situation in the republic depended on extratextual factors, mainly on the domestic national policy of the state the part of which is the language policy. As a result of military operations of mass migrations the social base of the Chechen language was sharply reduced. The disruption of the education system of the Chechen Republic aggravated the situation including the situation in the language sphere since the main channel of mastering of the standards of the Chechen language, first of all, of the written standards, is the education system. This circumstance, the destruction of the education system, being followed by the departure of the Russian population from the republic, including the teachers, considerably worsened the situation with knowledge of the Russian language.

The newest period of history of the Chechen Republic in the 21st century is wholesome for further development of the Chechen-Russian bilingualism as the Russian language is a teaching language in the republic education system. The promoting factor is a trend of gradual increase of the Russian and Russian-speaking population in the republic.

\section{Лumepamypa}

1. Богин Г.И. Обретение способности понимать: Введение в филологическую герменевтику. М.: Психология и Бизнес ОнЛайн, 2001.

2. Ильясова Р.С. Антонимия в чеченском и русском языках: сопоставительный аспект. Грозный, 2013.

3. Караулов Ю.Н. Русский язык и языковая личность. М., 1987.

4. Овхадов М.P., Шамилева Р.Д, Яхъяева А.А. Языковая ситуация в Чеченской Республике. Назрань, 2016. 175 с. 
5. Халидов А.И. Тенденции чеченско-русского двуязычия и эколингвистическая ситуация в ЧР // Современные проблемы науки и образования. 2015. № 1. URL: http://science-education.ru/1929-21854

6. Ilyasova R. Language Personality in the Context of Interaction of Language and Culture // Научный альманах стран Причерноморья. 2018. № 4. http://www.sciencealmanac.ru/issue/219/

\section{References}

1. Bogin G.I. Obretenie sposobnosti ponimat': Vvedenie v filologicheskuiu germenevtiku. [Attainment of ability to understand: Introduction to philological hermeneutics]. Moscow: Psychology and Business Online, 2001 (in Russian).

2. Ilyasova R.S. Antonimiia $v$ chechenskom i russkom iazykakh: sopostavitel'nyi aspekt. [Antonymy in the Chechen and Russian languages: comparative aspect]. Grozny, 2013 (in Russian).

3. Karaulov Yu.N. Russkii iazyk i iazykovaia lichnost'. [The Russian language and the language personality]. Moscow: 1987 (in Russian).

4. Ovkhadov M. R., Shamileva R. D, Yakhjyaeva A.A. Iazykovaia situatsiia v Chechenskoi Respublike. [The language situation in the Chechen Republic]. Nazran, 2016. 175 p. (in Russian).

5. Halidov A.I. Tendentsii chechensko-russkogo dvuiazychiia i ekolingvisticheskaia situatsiia v ChR. [Trends of the Chechen-Russian bilingualism and the ecolinguistic situation in the Chechen Republic]. Modern problems of science and education. 2015. No. 1. Available at: http://science-education.ru/1929-21854

6. Ilyasova $R$. Language Personality in the Context of Interaction of Language and Culture. Science Almanac of Black Sea Region Countries. 2018. No. 4. Available at: http://www.science-almanac.ru/issue/219/ 